\title{
Device Exposure Supplemental Qualifiers Dataset
}

National Cancer Institute

\section{Source}

National Cancer Institute. Device Exposure Supplemental Qualifiers Dataset. NCI

Thesaurus. Code C147207.

A dataset containing supplemental information, specifically non-standard variables, to parent records in the device exposure domain. 